O pós-abolição e o estigma do alienado no romance social O cemitério dos vivos, de Lima Barreto.

Revista Ensaios, vol. 14, jan-jun de 2019.

\title{
O pós-abolição e o estigma do alienado no romance social $O$ cemitério dos vivos, de Lima Barreto.
}

Patrick Silva dos Santos ${ }^{1}$

Resumo: A proposta deste artigo é fazer uma análise crítica em relação à alienação como, em partes, correspondente ao abandono social de determinados segmentos da população que não se encaixavam no projeto de modernização republicano. Portanto, para apreender certas questões em $O$ cemitério dos vivos, romance inacabado de Lima Barreto, utilizo o método da Crítica Integradora do sociólogo brasileiro, Antônio Candido, que nos permitiu extrair deste romance social elementos constitutivos da realidade social que estavam plasmados ficcionalmente.

Palavras-chaves: Lima Barreto; pós-abolição; alienação; exclusão; modernização republicana.

The post-abolition and the stigma of the alienated in Lima Barreto's social novel The Graveyard of the Living

Abstract: The purpose of this article is to make a critical analysis in relation to alienation as, in part, corresponding to the social abandonment of certain segments of the population that did not fit the republican modernization project. Therefore, to grasp certain issues in Lima Barreto's The Cemetery of the Living, an unfinished novel, I use the method of the Integrating Criticism of the Brazilian sociologist Antônio Candido, which allowed us to extract from this social novel constitutive elements of social reality that were fictionally shaped.

Keywords: Lima Barreto; post abolition; alienation; exclusion; republican modernization.

\footnotetext{
${ }^{1}$ Universidade Federal Fluminense (UFF), Programa de Pós-graduação em Sociologia (PPGS), Niterói, RJ, Brasil. patricksds@id.uff.br.
} 
O pós-abolição e o estigma do alienado no romance social $O$ cemitério dos vivos, de Lima Barreto.

Revista Ensaios, vol. 14, jan-jun de 2019.

Durante a Primeira República (1889 - 1930) no Brasil, diversos segmentos populacionais tiveram suas possibilidades de participação no "sonho republicano" cerceadas pelos mais variados mecanismos de controle social (BOMFIM, 1905; CARVALHO, 2015; SCHWARCZ, 2014, 2015, 2017, 2019; SEVCENKO, 2014). Outrora nos últimos anos da ordem imperial no Brasil, a ascensão social de indivíduos negros, mestiços e mulatos tinha sua aspiração correspondida, ainda que de forma limitada, em relação a outros setores populacionais (CARVALHO, 2017). Isto é, existiam caminhos que possibilitavam a busca de melhores alocações na estrutura social daquele momento e a educação, por exemplo, se constituía um desses caminhos possíveis. Inclusive, foi este o caminho trilhado pela família do escritor fluminense, Lima Barreto.

Afonso Henriques de Lima Barreto (1881 - 1922) nasceu no bairro de Laranjeiras (bairro da zona sul, da cidade do Rio de Janeiro). Seus pais eram negros pobres que possuíam um nível educacional invejável para a época (CARVALHO, 2017; SCHWARCZ, 2017). Sua mãe, Amália Augusta foi professora e proprietária do Externato Santa Rosa; enquanto, o seu pai, João Henriques de Lima Barreto foi tipógrafo da Imprensa Nacional. João Henriques chegou a fazer preparatórios para cursar medicina em meados do século XIX (BARBOSA, 2012; SCHWARCZ, 2017).

Lima Barreto estudou nas melhores escolas do Estado naquele período: Liceu Niterói e no Ginásio Nacional. Ingressou na Escola Politécnica, tradicional instituição de ensino superior brasileira para cursar Engenharia Civil. Todavia não chegou a concluir este curso por ter tido sucessivas reprovações e, concomitantemente, seu pai, João Henriques adoeceu. Após a tragédia familiar materializada na enfermidade do pai, Lima ingressou no serviço público e tornou-se o mantenedor de sua família. Contudo, se a engenharia se tornou algo distante devido às peripécias da vida, por outro lado, a literatura seria a sua redenção e o que dava sentido à sua vida. Não à toa Lima foi um dos críticos mais ácidos e incisivos nos desvelamentos das mazelas sociais da Primeira República Brasileira (BARBOSA, 2012; DIAS, 2013).

O literato e cronista das relações sociais espoliativas, cujo palco (GOFFMAN, 2002) para sua observação privilegiada se deu na cidade do Rio de Janeiro da Belle 
O pós-abolição e o estigma do alienado no romance social O cemitério dos vivos, de Lima Barreto.

Revista Ensaios, vol. 14, jan-jun de 2019.

époque ${ }^{2}$, Afonso Henriques de Lima Barreto, utilizou os espaços de que participava nos jornais, seu diário e a sua arte literária para tornar público os mais variados desajustes sociais cristalizados pela política dos primeiros anos republicanos no Brasil. Deste modo, é questão chave para esta análise entender o tipo de processo civilizador (ELIAS, 2011) que se desenvolveu por meio das relações sociais que aqui se estabeleceram: seja pelos indivíduos racialmente distintos e/ou seja entre o Estado configurado institucionalmente como uma república. Neste sentido, entender essas relações sobre uma forte pressão tradicional da Escravidão. Adaptando as formulações conceituais do sociólogo canadense, Erving Goffman, entendo essa instituição que moldou a sociabilidade racial e institucional brasileira como uma Instituição Total $^{3}$.

\section{Da Escravidão ao Pós-abolição: distanciamentos e continuidades}

Um dos processos mais pertinentes no que concerne ao modelo de sociabilidade estabelecido no Brasil, ou tomando emprestado os termos do sociólogo alemão, Norbert Elias: o processo civilizador que marca as relações sociais hierarquizadas aqui estabelecidas ainda hoje, possuem referências diretas às marcas enraizadas pela escravidão negra no país. No entanto, não tratarei aqui desta questão de forma exaustiva e nem pormenorizada, isso porque, o que me interessa aqui é fazer uma breve apresentação da problemática conjuntamente às mediações possíveis no que tange as proximidades e os distanciamentos das relações sociais praticadas durante e após o fim do regime de trabalho compulsório em solo brasileiro.

A instituição escravidão no Brasil perdurou por mais de três séculos de maneira heterogênea, pois, o trabalho dos homens e mulheres aqui escravizados estava presente

2A Belle Époque representou no Brasil um processo de modernização em diversas dimensões que buscava minimizar os signos remanescentes da ordem imperial e da colonização portuguesa. Do ponto de vista dos costumes as novas vogas a serem seguidas vinculavam-se a tradição e/ou modismos de raízes francesas. As grandes reformas urbanísticas colocadas em curso pelo Prefeito Pereira Passos no início do século XX simbolizam bem este período e que grupos sociais participariam dessa vida citadina.

3As Instituições Totais são definidas como locais de trabalho e/ou de residência onde um número grande de indivíduos possuem situação semelhante e, por conseguinte, são separados do conjunto mais amplo da sociedade, assim, levando uma vida fechada e formalmente administrada. Sendo essas Instituições responsáveis pela reconfiguração do "eu". 
O pós-abolição e o estigma do alienado no romance social O cemitério dos vivos, de Lima Barreto.

Revista Ensaios, vol. 14, jan-jun de 2019.

desde as grandes lavouras às pequenas plantações de subsistência. Até o Estado colonial, e mais tarde o imperial, possuíam escravos, estes descritos como escravos públicos ${ }^{4}$ (ROCHA, 2018).

No Brasil, "o sistema escravocrata transformou-se num modelo tão enraizado que acabou se convertendo numa linguagem, com graves consequências" (SCHWARCZ, 2019, p. 27). Essa linguagem na qual o sistema escravocrata se converteu no Brasil só foi possível pela importância que a escravidão teve não só na economia, mas também nas dinâmicas sociais e em seus efeitos psíquicos em todo o conjunto daquela sociedade. Segundo a antropóloga brasileira Lilia Moritz Schwarcz, tal potencialidade desse enraizamento deu-se pelo espraiamento do regime de trabalho compulsório por todo o país, moldando as relações sociais e "gestando" hierarquias raciais que viriam a ser solidificadas. Pois a escravidão

(...) no caso brasileiro, de tão disseminada ela deixou de ser privilegio de senhores de engenho. Padres, militares, funcionários públicos, artesãos, taverneiros, comerciantes, pequenos lavradores, grandes proprietários, a população mais pobre e até libertos possuíam cativos. E, sendo assim, a escravidão foi bem mais que um sistema econômico: ela moldou condutas, definiu desigualdades sociais, fez de raça e cor marcadores de diferença fundamentais, ordenou etiquetas de mando e obediência, e criou uma sociedade condicionada pelo paternalismo e por uma hierarquia muito estrita. (SCHWARCZ, 2019, p. 27-28)

Neste sentido, é possível aferir o peso que essa instituição milenar em suas mais diferentes roupagens ao longo da história humana, teve sobre os corpos e a psiquê de negros e negras aqui coisificados e também, sujeitos a toda a sorte de violências empregadas por seus proprietários, ainda, que sejam inegáveis as inúmeras lutas sociais por parte dos seres humanos aqui escravizados. Assim, reconheço a dimensão do conflito, que por si só, desfaz a ideia de passividade. Mas, por reconhecer que a dimensão da violência impetrada em suas inúmeras formas aos escravizados, significativamente, gerou grandes sequelas subsequentes (PATTERSON, 2008). A meu ver, se faz necessário o

4 Os escravos públicos correspondiam a uma modalidade especifica de cativos que pertenciam ao Estado. Como afirma a historiadora Ilana Peliciari Rocha (2018) No período colonial brasileiro os escravos públicos eram conhecidos como os "escravos do Real Fisco" e posteriormente, já no período imperial passarão a serem chamados de "escravos da nação" e o trabalho do qual eram submetidos concentravam-se nas diversas instituições públicas, como por exemplo, no Arsenal de Marinha, na Corte, nas colônias militares, nas fabricas, em obras públicas etc. 
O pós-abolição e o estigma do alienado no romance social O cemitério dos vivos, de Lima Barreto.

Revista Ensaios, vol. 14, jan-jun de 2019.

entendimento de imputar o caráter de uma Instituição Total à escravidão. Pois sua dinâmica pressupunha: controle, dominação, vigilância e a destruição do $e u$ e a adequação de um novo eu condizente com as dinâmicas impostas por essa instituição, mesmo que nem sempre tal reconfiguração do $e u$, pensando nas dinâmicas relacionais da escravidão brasileira tenha-se concretizado, ao menos, sem lutas e resistência.

Desde o momento que se tornava emergente os embates em torno do fim do regime de trabalho compulsório em solo brasileiro, por conta da desintegração da exploração do trabalho escravo em outras partes do globo. No Brasil mais especificamente, o tema foi tratado com certa cautela, por exemplo, podemos tomar o discurso anual do trono proferido por Dom Pedro II, em 1867, em que o imperador do Brasil anuncia que "o elemento serviu não pode deixar de merecer a vossa consideração na época apropriada" (DRESCHER, 2011, p. 507), essa cautela segundo ao imperador se fazia necessária para não prejudicar a propriedade já existente e, por conseguinte, evitar causar grandes transtornos a agricultura (DRESCHER, 2011). Neste sentido, os negócios comuns aos proprietários e aos próprios interesses do império vinham em primeiro plano. Portanto, equalizadas tais dimensões, poderiam pensar no fim progressivo desse regime desumanizador de trabalho (PRADO, 1895; BOMFIM, 1905).

Não obstante, paulatinamente, já vinham sendo refletidas maneiras de apagar o quantitativo negro no país, isso porque, com as pressões britânicas para o fim da escravidão e a inevitável inserção numa modernidade ocidental que pressupunha formas "modernas" de organização do trabalho e da economia. O que se colocava nos círculos mais restritos do poder era: findada a ordem escravagista o que fazer com um contingente populacional negro tão elevado? Dentre as muitas estratégias para a diminuição progressiva e/ou até mesmo o apagamento total do elemento negro da sociedade brasileira. Uma das saídas pensada na época foi a integração de um amplo contingente negro nas frentes militares brasileiras que batalhavam de forma conjunta com uruguaios e argentinos na Guerra do Paraguai ${ }^{5}$. Pois:

5 A Guerra do Paraguai foi um dos maiores confrontos já ocorridos ao longo da história do continente Sul americano. Essa guerra foi travada entre o bloco brasileiro, argentino e uruguaio contra o Paraguai, desde 
O pós-abolição e o estigma do alienado no romance social O cemitério dos vivos, de Lima Barreto.

Revista Ensaios, vol. 14, jan-jun de 2019.

Dada a relutância dos donos de escravos em abrir mão de seus escravos, o governo decidiu concentrar-se no recrutamento daqueles que pertenciam ao Estado e à Igreja. Por lei, os escravos teriam de ser libertados antes de integrarem o exército. (...) Nabuco de Araújo, o pai do futuro abolicionista [Joaquim Nabuco], recomendou que a 'captura' e a integração deles ocorresse em segredo, para evitar quaisquer recusas escravas de liberdade ou de fugas durante o serviço militar. (...) Outro membro do gabinete considerou o recrutamento como um passo em direção à emancipação via dizimação. Ao enviar os negros aos campos de batalha, como acontecera em outros lugares da América do Sul, a mortalidade aumentaria, ou seja, embranqueceria a configuração racial do Brasil de longo termo (...) (DRESCHER, 2011, p. 508509. Grifos meus)

Além dos focos de resistências a escravidão - onde negros e negras eram agentes ativos centrais nessas lutas (GOMES, 2005; DEL PRIORE, 2010; SCHWARCZ, 2015 e 2018). Paralelamente, foram sendo desenvolvidas uma série de leis graduais, simbolicamente violentas e conservadoras que desenhavam o desmonte formal da ordem escravagista, a saber: em 1871, foi implementada a Lei do Ventre Livre que garantia a liberdade dos filhos recém-nascidos das mulheres aqui escravizadas, mas, não influía o mesmo direito para as mães e, não obstante, ainda cabia ao senhor a opção de ratificar tal liberdade ou ficar com essas crianças até completarem 21 anos; segundo passo veio com a implementação da Lei dos Sexagenários, em 1885, que garantia a liberdade dos homens e mulheres escravizados idosos e/ou precocemente envelhecidos que muitas vezes já impossibilitados de trabalhar constituíam-se na prática geradores de despesas “desnecessárias" aos senhores ao invés de lucro; e, por fim, a Lei Áurea implementada no dia 13 de maio de 1888 que colocava um ponto final no regime escravocrata brasileiro. Entretanto, sem projeto algum de inclusão para o grande contingente de homens e mulheres antes mantidos na condição de propriedades privadas de seus senhores.

Em 1905, o médico sergipano Manoel José do Bomfim em seu vigoroso ensaio, $A$ América Latina: males de origem, ao tratar do caráter conservador dos estratos

o final de 1864 a 1870 . No centro de interesses conflitantes que gerou a guerra estavam disputas econômicas na região da Bacia Platina, territoriais e políticas que levaram a aliança entre os três países citados contra o Paraguai comandado a época pelo chefe de Estado, Francisco Solano López (1827-1870). 
O pós-abolição e o estigma do alienado no romance social O cemitério dos vivos, de Lima Barreto.

Revista Ensaios, vol. 14, jan-jun de 2019.

dominantes brasileiros e, de certa forma, das transformações que aqui se desenrolaram, apontava Bomfim que até nas transformações de cunho um pouco mais progressistas se observava o conservadorismo ${ }^{6}$ implícito nas práticas desses idealizadores. Como sugeriu Manoel Bomfim, quando foi abolida a Escravidão no Brasil, os abolicionistas e demais legisladores entenderam esse acontecimento como um processo completo, ou seja, findase a escravidão e, como num passe de mágica, estariam abolidas as desigualdades raciais no Brasil. Para os egressos do trabalho compulsório, tais desigualdades ampliaram-se na verdade. Isto é, foram acrescidas por desigualdades econômicas.

Qual seria a efetividade de uma abolição conservadora não aditivada por políticas públicas de inclusão destes indivíduos? Assim, Bomfim apontou em seu ensaio de 1905 os motivos de compreender como conservadora a abolição posta em prática no Brasil. Pois, ela relegava homens e mulheres outrora coisificados por uma instituição que perdurou nestas terras por mais de três séculos a um novo tipo de coisificação: a do abandono à própria sorte, sem nenhuma estratégia ou mecanismos de inclusão posto em prática pelo Estado.

É necessário expor que com a liberdade formal tivemos o influxo de novos mecanismos de dominação aceitos como legítimos. Pois, com a liberdade e com o status

$6 \mathrm{O}$ Conservadorismo Essencial é uma questão central em A América Latina: males de origem, pois é um elemento do caráter latino-americano, adquirido por meio da herança e educação transmitidas a nós por meio da relação mantida por séculos com os povos colonizadores do continente. Segundo Bomfim entre as qualidades a nós transmitidas, a mais sensivel e mais interessante, - por ser a mais perversa - é um conservantismo, não se pode dizer obstinado, por ser, em grande parte, algo inconsciente, entretanto, pode ser compreendido como um conservantismo essencial, mais efetivo que propriamente intelectual. Este é partindo dos pressupostos bomfimnianos o elemento gerador de visões societárias e de atuações estatais incompatíveis com o desenvolvimento saudável das repúblicas latino-americanas. Isso ocorre porque o conservadorismo essencial perpassa toda a vida social, nas mais variadas esferas, este não materializa somente nas dimensões políticas, mas na manutenção dos instrumentos obsoletos de produção, no trato com os diversos estratos sociais, no modus operandi das instituições, na impossibilidade de ampliação de direitos sociais, etc. Neste sentido, o conservadorismo materializa-se como entrave para um projeto de modernização que não esteja alinhado ao passado, e, também, por outro lado, efetivamente foi um obstáculo para o progresso social das jovens repúblicas da América do Sul, saídas do regime de exploração colonial. Todavia, a explicação para a força do conservadorismo descrito no ensaio histórico-sociológico do médico sergipano concentra-se na tentativa de atualização de privilégios ancorada nas tradições do passado, por isso Bomfim salienta que onde quer que surja uma forma de oposiçãoconservadora,háumprivilegioquesequermanter,éporissoqueeste conservadorismo resiste pura e simplesmente ao progresso, que, no limite, destruiria as vantagens dos grupos dominantes, e, também, afrontaria certos preconceitos e superstições. 
O pós-abolição e o estigma do alienado no romance social O cemitério dos vivos, de Lima Barreto.

Revista Ensaios, vol. 14, jan-jun de 2019.

cidadão formal, ocorreu a emergência de novos instrumentos de dominação e manutenção de privilégios comuns a uma ordem de organização estamental. Neste sentido, efetivouse um maior influxo das mais variadas teorias racialistas. Respostas "científicas" contrariamente diretivas ao atestado jurídico recém conquistado por negros e negras não mais inseridos numa ordem escravocrata. Mas, se por um lado, os códigos jurídicos atestavam uma dada condição formalmente comum a todos os cidadãos - por outro lado, a ciência neste momento se colocava como opositora a determinado estatuto legal (PRADO, 1895; BOMFIM, 1905; BARRETO, 1961; PATTERSON, 2008; DRESCHER, 2011; POLIAKOV, 1974; COSTA, 2006; HOFBAUER, 2006; DEL PRIORE, 2010; SCHWARCZ, 2014; SEVCENKO, 2014; BETHENCOURT, 2018). Desta forma, as teorias racialistas em suas mais variadas roupagens representaram o "novo" mecanismo de restrição de uma cidadania plena para os recém-libertos e seus descendentes. Então, de fato o pós-abolição representou para os segmentos populacionais historicamente postos à margem da sociedade, um momento de perceptível continuidade de relações hierarquizadas análogas ao passado escravocrata.

Por tudo isso, é que "na época da imediata pós-emancipação um sábio dito popular circulou pelas ruas do Rio de Janeiro: 'A liberdade é negra, mas a igualdade é branca'." (SCHWARCZ, 2019, p. 30-31). Tal dito popular só reforça a argumentação em relação a persistência dos padrões de desigualdades análogos ao processo civilizador brasileiro: a escravidão, que persiste em se atualizar nas mais variadas violências e na ausência de reparações concretas a toda uma população continuamente coisificada, e impedida de sonhar como parte integrante de um projeto de Brasil moderno.

Da autobiografia ao enredo da ficção: do estigma da alienação à tragédia pessoal de Lima Barreto

A observação da alienação para além de questões exclusivamente patológicas (FOUCAULT, 2017) antecede o período republicano no Brasil. Na ordem imperial, tal estigma já era mobilizado como uma das estratégias de exclusão de elementos populacionais indesejáveis, e, para além disso, representava um meio de abrir mão de 
O pós-abolição e o estigma do alienado no romance social O cemitério dos vivos, de Lima Barreto.

Revista Ensaios, vol. 14, jan-jun de 2019.

indivíduos abandonados à própria sorte. Esse mecanismo foi utilizado nos últimos anos do regime imperial; entretanto, foi dentro da ordem republicana que sua utilização mais ampla se consolidou (ENGEL, 2001).

Portanto, em diversos casos (não todos) a alienação representava de fato, um eufemismo para o desamparo social de grupos antes explorados como "máquinas" e agora descartados como "sucatas" indesejáveis e incompatíveis com o ideal modernizante desejado.

Segundo o médico, Jurandir Freire Costa (2006), tal imposição estigmatizante em torno da alienação extra patológica foi um condicionante antiliberal impetrado ideologicamente para intervir arbitrariamente no seio de um segmento específico da população brasileira. Desta forma, o alvo de tais medidas e dos mais variados diagnósticos alienantes eram preferencialmente negros e negras e os demais grupos advindos do "cruzamento" genético com esse grupo étnico-racial. No entanto, sustenta o médico, ainda que grande parte das doenças mentais, chamadas de constitucionais, fosse anteriormente relegada aos brancos, como por exemplo, a psicose maníaco-depressiva, a esquizofrenia, etc., de fato, isso pouco importava. Porque o que estava em jogo não eram certas patologias clínicas e sim o controle de elementos populacionais, numa ordem de iguais. Pois, os

(...) psiquiatras tinham nas estatísticas um pretexto para confirmar o preconceito racial. Os indivíduos não-brancos, sendo portadores hereditários de predisposição sifilítica, representavam um perigo para a constituição eugênica do Brasil. (...) O mesmo fenômeno repete-se com o alcoolismo. Nas décadas de 20-30, a maioria dos psiquiatras brasileiros afirmava que o alcoolismo era mais frequente no negro, por causa de sua herança racial. Entretanto, os negros antes de serem submetidos à engrenagem social das cidades, apresentavam um índice de alcoolismo claramente inferior ao das doenças constitucionais (esquizofrenia, psicose maníaco-depressiva etc.), que eram consideradas como atributo racial do homem branco. (...) Esta população já era, em grande parte, livre e urbanizada, o que nos leva a concluir que o alcoolismo crescia na medida em que se degradava o comportamento social e psíquico dos indivíduos, pressionados pela nova situação econômica em que viviam. (COSTA, 2006, p. 112)

O convívio com a alienação já aparecera na trajetória de vida de Lima Barreto, bem cedo. Ainda criança, devido as ligações de seu pai, João Henriques de Lima Barreto com o seu padrinho, o monarquista Afonso Celso (Visconde de Ouro Preto), e, com o 
O pós-abolição e o estigma do alienado no romance social $O$ cemitério dos vivos, de Lima Barreto.

Revista Ensaios, vol. 14, jan-jun de 2019.

aprofundamento das mudanças institucionais republicanas, para não ficar desempregado, João Henriques assume uma nova atividade laboral e muda-se com os filhos para a Colônia de Alienados, da Ilha do Governador em 1890. Na época, Lima tinha apenas 8 anos de idade. O convívio de Lima Barreto com a dinâmica da colônia era limitado, pois, ainda que subisse em árvores, se relacionasse com os internos, e também, brincasse no enorme espaço da colônia. Tal dinâmica era comum à vida cotidiana da jovem criança aos fins de semana. Durante a semana, o jovem Lima Barreto dedicava-se aos estudos na cidade, longe da Ilha que o menino tanto adorava (SCHWARCZ, 2017).

Mais tarde, em 1897, Lima Barreto ingressou no curso de Engenharia Civil na Escola Politécnica ${ }^{7}$ (localizada no Largo do São Francisco, região central, da cidade do Rio de Janeiro). Lá, fez alguns amigos e também desafetos, acumulou algumas reprovações devido a sua pouca aptidão para as ciências exatas (SCHWARCZ, 2017). Todavia, a inesperada doença de seu pai (neurastenia ${ }^{8}$ ), ataca em cheio os planos do futuro escritor fluminense. Mais precisamente, em 1902, a loucura adentra a vida da família Barreto para não mais largá-los. Assim, devido ao estado mental debilitado de João Henriques, Lima Barreto com 21 anos de idade irá se responsabilizar pelos cuidados do pai e toda a família, deixando para trás os cinco anos de Politécnica.

Lima Barreto partiu junto à família para um novo lar. Ficará no passado a Ilha do Governador e o novo endereço da família de Lima foi nos subúrbios do Rio de Janeiro, no Bairro de Todos os Santos (zona norte da cidade) e, além da aposentadoria do pai enfermo, Lima Barreto contará com o seu salário de amanuense da Secretaria de Guerra para manter sua família (BARBOSA, 2012; SCHWARCZ, 2017). A partir desse ponto da vida, iniciasse sua trajetória dividida entre o serviço público, a devoção às letras e ao

\footnotetext{
7 Hoje no prédio funciona o Instituto de Filosofia e Ciências Sociais (IFCS), da Universidade Federal do Rio de Janeiro (UFRJ).

8Como descreveu em sua biografia sobre Lima Barreto, a antropóloga Lilia Schwarcz (2017) a neurastenia é um transtorno psicológico e físico, cujas motivações tanto são endógenas como exógenas. Isto é, na primeira dimensão é correspondente a uma predisposição genética a ansiedade e depressão - ao passo que na segunda dimensão refere-se a problemas relacionados a trabalho exaustivo, frustrações e, também, situações traumáticas.
} 
O pós-abolição e o estigma do alienado no romance social O cemitério dos vivos, de Lima Barreto.

Revista Ensaios, vol. 14, jan-jun de 2019.

álcool. Sendo as letras e o álcool sua companheira e companheiro, ambos presentes até o último suspiro de vida do escritor.

Afonso Henriques de Lima Barreto foi internado em duas ocasiões pelo consumo excessivo de bebidas alcoólicas, a saber: a primeira em 1914, no Hospício de Alienados (que funcionava na Praia Vermelha, no Bairro da Urca, zona sul, da cidade do Rio de Janeiro) e a segunda internação em 1919 na mesma instituição. Pistas para desvelar essa tragédia pessoal são muitas. Vão desde as muitas frustrações em relação as expectativas criadas em torno de sua produção literária, as posições sociais e mobilidade rígidas mediadas por caracteres raciais, a doença do pai e o abandono de projetos próprios para tornar-se mantenedor de sua família. Dentre as mais variadas possibilidades, Carlos Maul faz um instigante relato em relação a Lima Barreto:

Fui seu amigo sem ser seu companheiro de noitadas no bar do Braço de Ferro. Questão de diferença de temperamento e de falta de tempo vadio para encher de desbragamentos boêmios. Aos que estudam a obra vasta e espantosa de Afonso Henriques de Lima Barreto, produzida em prazo curto e reveladora de uma cultura que não se obtem sem muito esforço e continuidade, parece um milagre - ter ele conseguido tanto numa vida breve e agitada como foi a sua. Certos analistas superficiais pretendem ver no romancista suburbano um recalcado contra uma sociedade sofisticada que o desprezaria sob a pressão do preconceito de côr. Êle seria o porta-voz da revolta dos humildes das zonas pobres em hostilidade aos senhores das zonas abastadas... Daí o notar-se em seus escritos a predominância dos personagens obscuros e sofredores. (MAUL, 1967, p. 35-36)

Prossegue Carlos Maul sobre sua crítica em relação a tal movimento de análise em relação ao escritor de Todos os Santos:

Tenho motivos pessoais para não aceitar como moeda sã essa que corre com fumos de psicologia para nos pintar um Lima Barreto mulato com ódio de branco, pois nunca lhe ouvi qualquer queixa ou comentário que denunciasse pensamentos nesse sentido. Aliás os seus mais afetuosos amigos eram todos brancos e ele os estimava bastante. Mas por que se embriagava Lima Barreto com frequência? Pergunta-se se não teria havido aí a intervenção de um amor frustrado. Buscaria nos excessos alcóolicos o esquecimento... Pelo menos foi o que me deu a entender num de seus momentos de agitação, ao revelar-me que determinado indivíduo se casara com a mulher que êle elegera para alvo de seus afetos. Chegou a citar um nome, nada disse que denunciasse a discriminação racial. Em todo o caso, o certo é que ninguém soube que Lima Barreto houvesse tido na vida uma ligação amorosa ostensiva. (MAUL, 1967, p. 36) 
O pós-abolição e o estigma do alienado no romance social O cemitério dos vivos, de Lima Barreto.

Revista Ensaios, vol. 14, jan-jun de 2019.

Ainda que o intelectual Carlos Maul tenha conhecido o escritor Lima Barreto no período em que dirigiu junto a José Veríssimo Filho a Revista Floreal ${ }^{9}$ (MAUL, 1967). Pode ser que o relato de Carlos Maul faça sentido e seja verdadeiro do ponto de vista de sua relação com Lima. No entanto, isso não significa que em relação a outros amigos Lima Barreto não tenha descrito outras coisas que viriam a entrar em conflito com esta exposição. Pois, devemos nos perguntar: qual era o grau de amizade entre ambos? Até que ponto Lima confiava questões mais íntimas ao amigo? Até que ponto tais questões mais angustiantes para o autor não permaneciam confinadas nele mesmo? O que é correto afirmar: é que o relato de Carlos Maul, contemporâneo de Lima Barreto, foi extraído de sua memória e também descreve as angústias de seu amigo (Lima Barreto) já falecido; logo, impossibilitado de confirmar tão intrigante e bombástico relato. Evidentemente, o relato de Maul difere (em muito) das perspectivas de pesquisas atuais em relação a Lima, do próprio diário íntimo e, também, do diário do hospício, do escritor de Todos os Santos. Pois, distintamente confessava Afonso Henriques de Lima Barreto:

\begin{abstract}
Muitas causas influíram para que viesse a beber; mas, de tôdas elas, foi um sentimento ou pressentimento, um mêdo, sem razão nem explicação, de uma catástrofe doméstica sempre presente. Adivinhava a morte de meu pai e eu sem dinheiro para enterrá-lo; previa moléstias com tratamento caro e eu sem recursos; amedrontava-me com uma demissão e eu sem fortes conhecimentos que me arranjassem colocação condigna com a minha instrução; e eu me aborrecia e procurava distrair-me, ficar na cidade, avançar pela noite adentro; e assim conheci o chopp, o whisky, as noitadas, amanhecendo na casa dêste ou daquele. (BARRETO, 1961, p. 47-48).
\end{abstract}

Reconheço que um dos traços marcantes do ator social Lima Barreto fora sua ambivalência e seus muitos bovarismos ${ }^{10}$. Mesmo assim, as respostas exatas que motivaram a tragédia pessoal de Lima Barreto não sabemos. Infelizmente, o

\footnotetext{
9 Revista fundada em 1907, de maneira coletiva junto a jovens intelectuais pertencentes ao círculo íntimo de Lima Barreto. Contudo, o idealizador deste projeto que se materializou na Revista Floreal, foi o editorchefe da revista: Afonso Henriques de Lima Barreto.

100 Bovarismo é um conceito desenvolvido pelo filósofo francês, Jules de Gaultier (1858-1942) em sua Teoria do Bovarismo. Para Gaultier (2006) o bovarismo corresponde ao poder conferido aos indivíduos de conceberem-se de forma diferente do que são realmente. A inspiração para esta formulação conceitual se deu, por meio do estudo, em torno do romance Madame Bovary, do escritor francês, Gustave Flaubert (1821-1880).
} 
O pós-abolição e o estigma do alienado no romance social O cemitério dos vivos, de Lima Barreto.

Revista Ensaios, vol. 14, jan-jun de 2019.

desvelamento preciso da questão se apagou em 1 de novembro de 1922, com o fechar definitivo dos olhos do escritor carioca.

\title{
Os estigmatizados da república em: $O$ cemitério dos vivos
}

No romance póstumo e inacabado O Cemitério dos Vivos, do escritor fluminense Afonso Henriques de Lima Barreto, publicado em 1956; temos um panorama extremamente rico das dinâmicas internas de uma instituição de reclusão de alienados, o hospício. O romance foi publicado inacabado, mas como sugeriu o acadêmico brasileiro Alfredo Bosi (2008), esta obra literária tinha tudo para ser o melhor trabalho literário de Lima Barreto. Ainda que a literatura brasileira "já conte com um alto número de memórias e escritos autobiográficos, são raras as obras que possam valer como testemunhos diretos e coerentes de um estado de opressão e humilhação" (BOSI, 2008, p. 13). Com certeza, estas são características marcantes do romance aqui trabalhado.

Por si só, o relato feito pelo escritor carioca após a sua segunda internação no Hospício de Alienados, em 1919, já é extremamente caro a uma parcela considerável da população que aqui conheceu toda a sorte das mais variadas formas de violência. Então, é certo afirmar que "um livro como este é rico em possibilidades de análise e reflexão sociológicas" (BECKER, 2009, p. 242). Sendo assim, as questões sociológicas já embutidas no romance de Lima Barreto nos possibilita desvelar pontos significativos. Pois os

\begin{abstract}
(...) romances podem ter, portanto, além de suas qualidades como obras literárias, qualidades como análises sociais. (...) Romances realistas da vida social com frequência oferecem uma alternativa a um tipo semelhante de análise sociológica - alternativa que apresenta mais detalhes dos processos envolvidos e mais acesso ao pensamento rotineiro das pessoas envolvidas. Esta é uma das razões por que muitos sociólogos usaram romances como fontes de conhecimento social (BECKER, 2009, p. 242).
\end{abstract}

A segunda parte de $O$ Cemitério dos Vivos marca a entrada do protagonista, Vicente Mascarenhas no Hospício de Alienados, na Praia Vermelha (bairro da Urca) bem num dia de Natal, no ano de 1919. E, é com extrema lucidez que se iniciam as reflexões em torno de sua internação e da violência de sua condução até aquela instituição de reclusão destinada ao "confinamento" da "loucura". Ao colocá-los lado a lado (ou seja, o diário 
O pós-abolição e o estigma do alienado no romance social O cemitério dos vivos, de Lima Barreto.

Revista Ensaios, vol. 14, jan-jun de 2019.

do hospício e o romance), há, porém, um movimento que busca induzir o leitor a um mergulho no real dentro do ficcional. O protagonista, dedica as suas primeiras queixas a instituição policial:

A polícia, não sei como e porque, adquiriu a mania das generalizações, e as mais infantis. (...) todo o cidadão de côr há de ser por fôrça um malandro; e todos os loucos hão de ser por fôrça furiosos e só transportáveis em carros blindados (BARRETO, 1961, p. 151-152).

E, mais a frente, confessa Vicente Mascarenhas:

Feria-me também o meu amor-próprio ir ter ali pela mão da polícia, doía-me; e, mais me doeu, quando, nesse dia de Natal, eu tomei café num pátio, sem ser mesa, e, sem ser mesa, com prato sôbre os joelhos, comi a refeição elementar que me deram, servida numa escudela de estanho e que eu levava à bôca com uma colher de penitenciária (BARRETO, 1961, p. 153).

O romancista social Lima Barreto aqui embutiu reflexões sociais extremamente pertinentes em sua criatura (Vicente Mascarenhas). Por meio dos questionamentos e angústias descritas pelo personagem, possibilitou-me refletir sobre o papel policial no que concerne ao uso da violência direcionado a determinados segmentos populacionais, os usos tardios da "ciência" racialista no contexto brasileiro e seus efeitos na dinâmica social, e também, a marginalidade exemplificada por meio do trato aos "loucos indigentes" que chegavam à instituição de confinamento de alienados pelas mãos da polícia - o que era completamente distinto, quando a internação se dava chancelada pelos familiares.

É curioso, observar na descrição de Mascarenhas, a potencialidade dos estereótipos racializados impregnados na psiquê dos agentes policiais, e, como isso, se reproduz socialmente ao lidar com esses grupos estigmatizados. Todavia, o que denota todo um aspecto ideológico deste pressuposto, se dá na dimensão do uso tardio destes esquemas de pensamento político-ideológicos e classificatórios, que marcaram todo um debate amplo dentro das sociedades europeias. Para o historiador Francisco Bethencourt (2018), os mais variados esquemas discriminatórios entre os seres humanos remontam à antiguidade clássica. Mas, será no período moderno que a classificação dos seres humanos passou a comportar supostos atributos físicos, psicológicos e políticos imutáveis a cada grupo "racial". Tal perspectiva veio a ser inaugurada, em 1735, com a publicação de Systema Naturae, do médico, zoólogo, botânico e historiador natural sueco, Carl 
O pós-abolição e o estigma do alienado no romance social $O$ cemitério dos vivos, de Lima Barreto.

Revista Ensaios, vol. 14, jan-jun de 2019.

Linnaeus (1707-1778), conhecido pelo grande público, como Lineu. Desde então, surgiram inúmeros teóricos e teorias pseudocientíficas (desenvolvidas desde o século XVIII até o início do século XX) cuja finalidade era legitimar a hierarquização da raça humana.

O que chama a atenção é que mesmo com um fluxo tardio dessas teorias em solo brasileiro, sendo, seu uso dissimulado/adaptado a realidade local (SCHWARCZ, 2014), a polícia aqui descrita por Vicente Mascarenhas agia de forma arbitraria e/ou preconceituosa com os grupos que a ciência da época buscava (na sua adaptação local) inferiorizar. Noto, para fins de exemplificação, a narrativa que, no prosseguir do romance, Mascarenhas profere sobre a Seção Pinel, do hospício:

\begin{abstract}
Na Secção Pinel, num pátio que ficavam os mais insuportáveis, dez por cento dêles andavam nu ou seminu. Êsse pátio é a cousa mais horrível que se pode imaginar. Devido a pigmentação negra de uma grande parte dos doentes aí recolhidos, a imagem que se fica dêle, é que tudo é negro. O negro é a côr mais cortante, mais impressionante; e contemplando uma porção de corpos negros nus, faz ela que as outras se ofusquem no nosso pensamento (BARRETO, 1961, p. 185).
\end{abstract}

A utilização de uma miríade de cores (SCHWARCZ, 2018) em sua produção literária como um todo se coloca como um instrumento demarcador que viabiliza a acomodação de categorias importantes, como: geração, classe social, origem, hierarquia etc., que no seio de sua produção são de grande importância para os fins que o escritor buscava conseguir com sua arte literária. Então, podemos afirmar que, ao apresentar que no pátio da Seção Pinel a “cor mais cortante é a cor negra”, o escritor de Todos os Santos, evidencia uma mediação direta entre uma condição, mais ou menos, legível entre pobreza e a cor da pele; como vincula-se, dialeticamente, cor da pele a alienação. Portanto, Lima Barreto apresenta no núcleo de sua obra ficcional elementos cognitivos que permeavam outras dinâmicas sociais. A cor da pele, a priori naquele momento servia como atestado primeiro para a loucura (antecedendo um diagnóstico médico) e até mesmo para a criminalidade.

De fato, os negros eram a maioria naquele pátio, não por serem mais propensos à alienação, como institucionalmente era aceito pelo Estado e suas instituições, orientados pela ciência europeia da desigualdade e degeneração das "raças humanas". Sua 
O pós-abolição e o estigma do alienado no romance social O cemitério dos vivos, de Lima Barreto.

Revista Ensaios, vol. 14, jan-jun de 2019.

construção enquanto o grupo maioritário da instituição, vincula-se invariavelmente ao abandono e a sua degradação social. Porquanto, isso não era digno de reflexão por parte dos grupos sociais que se beneficiavam dessa nova coisificação e/ou atestado de inferioridade para os homens e mulheres que antes eram enxergados como meros instrumentos de trabalho.

Como bem me orienta analiticamente em torno deste problema, o sociólogo alemão, Max Weber (1979) em seu estudo sobre o sistema de castas no núcleo societário hindu, na Índia; notou que os párias que representavam os indivíduos que naquela sociedade estariam fora do sistema piramidal de estratificação social, ainda assim, possuíam uma função social relacional às demais castas indianas bem demarcadas e compreendidas. Pois, a legitimação da ordem vigente naquele sistema de estratificação dava-se em relação aos párias. Ou seja, era por meio dos ditos intocáveis que até mesmo as castas inferiores eram distinguidas positivamente.

Não à toa, no desenrolar da trama de $O$ Cemitério dos Vivos, o interno do hospício Vicente Mascarenhas reflete da seguinte forma: "era também pela minha descendência que eu sofria particularmente" (Barreto, 1961, p. 211) e o protagonista conclui esta passagem refletindo criticamente sobre a dimensão secundária do problema (isso para não dizer, ilógica), em seus pensamentos a "tal hereditariedade dos sábios... E me reportaram tôdas as dúvidas, que eu e tanta gente tinha trocado essa antiga crendice popular, agora transformada em artigo de fé" (BARRETO, 1961, p. 211). No entanto, na quinta parte do romance, Vicente Mascarenhas já inicia desconstruindo tais maneiras de observação e de entendimento dos internos ancoradas nos pressupostos deterministas de hereditariedade, amplamente reproduzidos socialmente como o mais alto dos saberes científicos da época. Assim, a criatura do escritor Lima Barreto questiona e desmonta sistematicamente tais concepções:

(...) uma explicação da loucura, mecânica, científica, atribuída a falta ou desarranjo de tal ou qual elemento ou órgão da nossa natureza, parece que só há para raros casos, se há. (...) Procuram os antecedentes, para determinar a origem do paciente que está ali, como herdeiro de taras ancestrais; mas não há homem que não as tenha, e se elas determinam loucura, a humanidade tôda seria de loucos. Cada homem representa a herança de um número infinito de homens, resume uma população, e é de crer que nessa houvesse fatalmente, pelo menos, um degenerado, um alcoólico, etc. etc. (...) A explicação é 
O pós-abolição e o estigma do alienado no romance social O cemitério dos vivos, de Lima Barreto.

Revista Ensaios, vol. 14, jan-jun de 2019.

acomodada, mas não é leal, antes traduz o desejo de não invalidar uma sentença (BARRETO, 1961, p. 218).

Observo aqui, que por meio da crítica de seu personagem, o romancista social, Lima Barreto buscava influir por meio de sua arte literária num debate, que se colocava no seio da sociedade brasileira daquele período como a voga científica amplamente aceita e sem grandes contestações pelo conjunto mais amplo da população. E, por fim, o que estava por detrás dessas práticas médicas, no limite, era tratar com terapêuticas médicas problemas de cunho sociais mediados por preconceitos cristalizados.

Em A microfísica do poder, o filósofo francês, Michel Foucault afirmava que desde o século XIX, a funcionalidade dos hospícios, justificava-se, por assim dizer, por uma relação harmoniosa dimensionada em meio as "exigências da ordem social, que pedia proteção contra a desordem dos loucos" (FOUCAULT, 2017, p. 209). Ora, imaginem como era difícil para os homens e mulheres que chegavam a uma situação extremada de degradação social? Vicente Mascarenhas assim descreve:

\begin{abstract}
O terrível nessa cousa de hospital é ter-se de receber um médico que nos é impôsto e muitas vêzes não é da nossa confiança. Além disso, o médico que tem em sua frente um doente, de que a polícia é tutor e a impersonalidade da lei, curador, por melhor que seja, não o tem mais na conta de gente, é um náufrago, um rebotalho da sociedade, a sua infelicidade e desgraça podem ainda ser úteis à salvação dos outros, e a sua teima em não querer prestar êsse serviço aparece aos olhos do facultativo, como a revolta de um detento, em nome da Constituição, aos olhos de um delegado de polícia. A constituição é lá pra você? (BARRETO, 1961, p. 219).
\end{abstract}

Por meio da constatação feita pelo personagem Vicente Mascarenhas, posso afirmar que da mesma forma que no período de crise imperial, recém libertos pela Lei dos Sexagenários, por exemplo, eram encaminhados aos hospícios devido a sua condição de mendicância nas grandes cidades, após a conquista de uma "liberdade" sem estratégias de reparação por parte do Estado, por um lado, e também o abandono sem o mínimo reparo por parte dos seus antigos senhores, por outro lado (SCHWARCZ, 2017). Reafirmo assim, a ideia de que a alienação em muitos casos simbolizava um eufemismo para o desamparo e abandono social à própria sorte.

Na verdade, o que Lima Barreto consegue apresentar por meio de seu personagem é um testemunho vivais do quão dissimulado se colocava o Estado para os setores 
O pós-abolição e o estigma do alienado no romance social O cemitério dos vivos, de Lima Barreto.

Revista Ensaios, vol. 14, jan-jun de 2019.

marginalizados da população brasileira. Por exemplo, na sentença transcrita aqui onde Mascarenhas reflete "aos olhos de um delegado de polícia. A constituição é lá pra você? ${ }^{11}$ ". É ratificada a ideia de ausência de uma cidadania plena para todo o conjunto da sociedade, ao menos, do ponto de vista prático. Desta maneira, o que fica claro é que para parte considerável da população não eram só as benesses estatais que estavam distantes, mas o próprio estatuto cidadão equânime também o era, em muito distante.

Em: Lima Barreto: um triste visionário, Lilia Moritz Schwarcz sintetiza de maneira cirúrgica a arte literária deste importante ator social dos subúrbios - criador e criatura daquela cidade do Rio de Janeiro das primeiras décadas republicanas:

(...) Lima mostrava nas letras como a própria estrutura social brasileira tratava a cidadania plena dos afrodescendentes e o quanto a escravidão permanecia como uma espécie de herança cujo confronto era sempre adiado. E por isso destacar as cores sociais significava enfrentar uma contradição central da sociedade. (...) Não restam dúvidas de como, de um lado, a realidade social era seu fermento na construção de suas criaturas, no desenho de seus destinos, na discriminação dos preconceitos, na discrição dos padrões de sociabilidade distintos que iam sendo criados durante a República (SCHWARCZ, 2017, p. 429).

O romance publicado de maneira póstuma, em 1956, O Cemitério dos Vivos, ainda que circunscrito como obra ficcional inacabada num contexto de entrada nos anos 1920, é um romance que ainda diz muito sobre as persistências das hierarquias de mando e desmandos a que um setor específico da população ainda está sujeito - e também, sobre as demais formas de violência. O seu conteúdo por mais doloroso e caro para uma fração populacional historicamente excluída do projeto de construção nacional, deve ser encarado de frente. O texto de Lima Barreto oferece possibilidades de interpretação do Brasil do passado e infelizmente do presente também. Porque, sua literatura torna legível as continuidades com o passado escravocrata ainda encrostado no tecido social brasileiro.

11 Por analogia, podemos tratar desse abandono social dos homens e mulheres, negros e negras, mestiças e mulatos - por meio, do processo de descivilização do gueto, formulado conceitualmente pelo sociólogo francês, Loïc Wacquant (2008). Fazendo uso do conceito sociológico de processo civilizador do sociólogo alemão, Norbert Elias -, Wacquant propõe que nas metrópoles ocidentais coexistindo com processos integrados - havia um processo em curso de desintegração arquitetado para afastar as populações negras, da participação equânime das dinâmicas de construção nacional. Ou seja, para esses grupos historicamente marginalizados caberiam o afastamento sistemático das áreas mais valorativas das cidades, e sua, inclusão nos pontos desassistidos pelo poder estatal. 
O pós-abolição e o estigma do alienado no romance social O cemitério dos vivos, de Lima Barreto.

Revista Ensaios, vol. 14, jan-jun de 2019.

\section{Conclusão}

Em síntese, a ideia do artigo foi fazer uma reflexão crítica em torno dos conteúdos sociológicos embutidos no romance ficcional inacabado, O Cemitério dos Vivos, do escritor carioca, Afonso Henriques de Lima Barreto. Para pensar na metamorfose das categorias socialmente aceitas em cada período, o quê, no limite, mascara o abandono social presente entre nós. Isto é, a persistência de hierarquias e costumes enraizados no tecido social brasileiro advindos da "nossa" Instituição Total: o regime escravocrata, formalmente findado em 13 de maio de 1888. As marcas desses mais de três séculos de coisificação de seres humanos ainda persistem como perversas cicatrizes deslocadas para um único seguimento social que, ainda hoje, as sente de fato.

Ora, por analogia podemos identificar que o alienado ou detido/internado nos hospícios (maioria de pele negra) de outrora, a saber, é hoje: o favelado, o presidiário, o menor de rua, as jovens prostitutas - relegados ao aprisionamento simbólico e/ou real. A maioria dos homicídios que ocorrem no Brasil tem por vítimas diletas jovens negros; a maioria das mulheres que aqui são estupradas e mortas são mulheres negras; os menores de rua das grandes cidades brasileiras apresentam as mais variadas tonalidades de epiderme negra. O que podemos notar com tudo isso? É que desde a abolição da escravidão no Brasil a inventividade e/ou disposição para causar dor e sofrimento a um grupo é estruturalmente perversa na realidade brasileira.

Por fim, acredito que a potencialidade da investigação do abandono social e da exclusão racial em meio aos escritos de Lima Barreto muito se devem à persistência dessas estruturas enraizadas na sociedade brasileira. Isso faz da arte literária do escritor carioca atemporal. Talvez, se o Brasil tivesse se desvinculado das correntes e dos grilhões da escravidão de fato, não sei se tantos pesquisadores e pesquisadoras estariam debruçados sobre os mais variados materiais produzidos pelo cronista da cidade maravilhosa. Como sugeriu o historiador, Antonio Arnoni Prado:

Temos que ler Lima Barreto porque não somos um país livre, não somos um país integralmente livre. Temos que ler Lima Barreto porque somos um país socialmente injusto, somos um país onde os pobres continuam pobres e as elites continuam no lugar delas. Não é para aprender português que se lê Lima 
O pós-abolição e o estigma do alienado no romance social O cemitério dos vivos, de Lima Barreto.

Revista Ensaios, vol. 14, jan-jun de 2019.

Barreto, lê-se Lima Barreto para aprender a ser brasileiro (MINISTÉRIO DA EDUCAÇÃO, 2005, sp, Apud, PRADO, 2005, sp).

Não à toa, Lima ainda em vida descrevia que a arte é um fenômeno voltado para a transformação social. Então, enquanto os desajustes do passado persistirem - nós, os brasileiros e brasileiras, sobretudo os excluídos e as excluídas de todo e qualquer projeto de modernização que se deu no Brasil. Ao menos teremos a nosso lado a pena ácida de Lima Barreto. Por fim, o romancista dos subúrbios por meio de sua arte nos impossibilitou, enquanto brasileiros e brasileiras de esquecer o quão injusto, dissimulado e violento é o Brasil com parte de sua população. O que por si só, desmonta o mito da democracia racial que entre nós (brasileiros) nunca houve.

\section{Referências}

BARBOSA, Francisco de Assis. A vida de Lima Barreto. 10. ed. Rio de Janeiro: José Olympio, 2012.

BARRETO, Lima. Diário Íntimo - memórias. 2. ed. São Paulo: Brasiliense, 1961.

1961.

O cemitério dos vivos - memórias. 2. ed. São Paulo: Brasiliense,

BECKER, Howard Saul. Falando da sociedade: ensaios sobre as diferentes maneiras de representar o social. Rio de Janeiro: Jorge Zahar, 2009.

BETHENCOURT, Francisco. Racismos: das Cruzadas ao século XX. São Paulo: Companhia das Letras, 2018.

BOMFIM, Manoel. A América Latina: males de origem. Paris: Garnier, 1905.

BOSI, Alfredo. O cemitério dos vivos. Testemunho e ficção. Literatura e Sociedade, São Paulo (USP), v. 10, 2008. p. 18-33.

CANDIDO, Antonio. O discurso e a cidade. São Paulo: Duas cidades, 1993.

CARVALHO, José Murilo de. Os bestializados: o Rio de Janeiro e a República que não foi. 3. ed. São Paulo: Companhia das Letras, 2015.

CARVALHO, Maria Alice Rezende de. Três pretos tristes: André Rebouças, Cruz e Sousa e Lima Barreto. Topoi. Revista de História, Rio de Janeiro, v. 18, n. 34, 2017. p. 6-22. 
O pós-abolição e o estigma do alienado no romance social O cemitério dos vivos, de Lima Barreto.

Revista Ensaios, vol. 14, jan-jun de 2019.

COSTA, Jurandir Freire. História da psiquiatria no Brasil: um corte ideológico. 5. ed. Rio de Janeiro: Garamond, 2006.

DEL PRIORE, Mary. Uma breve história do Brasil. São Paulo: Planeta do Brasil, 2010.

DIAS, Regina Maria Santos. Lima Barreto: uma máquina de guerra na cidade do Rio de Janeiro. Curitiba/PR: Appris, 2013.

DORATIOTO, Francisco. Maldita guerra: nova história da Guerra do Paraguai. São Paulo: Companhia das Letras, 2002.

DRESCHER, Seymour. Abolição: uma história da escravidão e do antiescravismo. São Paulo: Ed. Unesp, 2011.

ELIAS, Norbert. O processo civilizador, volume 1: uma história dos costumes. 2. ed. Rio de Janeiro: Zahar, 2011.

Rio de Janeiro: Zahar, 1993.

O processo civilizador, volume 2: formação do Estado e civilização. . Mozart, sociologia de um gênio. Rio de Janeiro: Zahar, 1995.

\& SCOTSON, John L. Os estabelecidos e os outsiders: sociologia das relações de poder a partir de uma pequena comunidade. Rio de Janeiro, Zahar, 2000.

ENGEL, Magali Gouveia. A loucura, o hospício e a psiquiatria em Lima Barreto: críticas e cumplicidades. In: CHALOUB, Sidney et al (org). Artes e ofício de curar no Brasil. Campinas/SP: Ed. Unicamp, 2003. p. 57-98.

Os delírios da razão: médicos, loucos e hospícios (Rio de Janeiro, 1830-1930). Rio de Janeiro: Fiocruz, 2001.

FLAUBERT, Gustave. Madame Bovary. São Paulo: Abril, 1970.

FOUCAULT, Michel. Microfísica do Poder. 5. ed. Rio de Janeiro: Paz e Terra, 2017.

Vozes, 2014. Vigiar e Punir: nascimento da prisão. 42. ed. Petrópolis/RJ:

FREYRE, Gilberto. Casa-grande \& senzala. Rio de Janeiro: Record, 1998.

GAULTIER, Jules de. Le Bovarysme: mémoire de la critique. Paris: Presses de I’Université Paris-Sorbonne, 2006.

GOFFMAN, Erving. Manicômios, prisões e conventos. 8. ed. São Paulo: Perspectiva, 2008. 
O pós-abolição e o estigma do alienado no romance social $O$ cemitério dos vivos, de Lima Barreto.

Revista Ensaios, vol. 14, jan-jun de 2019.

Estigma: notas sobre a manipulação da identidade deteriorada.

4. ed. Rio de Janeiro: Zahar, 1982.

A representação do eu na vida cotidiana. 10. ed. Petrópolis/RJ:

Vozes, 2002.

GOMES, Flávio. Palmares: escravidão e liberdade no Atlântico Sul. São Paulo: Contexto, 2005.

HOFBAUER, Andreas. Uma história de branqueamento ou o negro em questão. São Paulo: FAPESP/Ed. Unesp, 2006.

KEHL, Maria Rita. O bovarismo brasileiro: ensaios. São Paulo: Boitempo, 2018.

MAUL, Carlos. Meu encontro com Lima Barreto. In: MAUL, Carlos. O Rio da Bela Época. Rio de Janeiro: São José, 1967. p. 35-37.

MINISTÉRIO DA EDUCAÇÃO- TV Escola. Lima Barreto: um grito brasileiro. Série mestres da Literatura (documentário). Brasília, 2005.

PATTERSON, Orlando. Escravidão e Morte Social: um estudo comparativo. São Paulo: Ed. Usp, 2008.

POLIAKOV, Léon. O mito ariano. São Paulo: Perspectiva/Editora da USP, 1974.

PRADO, Eduardo. A illusão americana. 2. ed. Paris: Armand Colin et Cie, Editeurs, 1895.

ROCHA, Ilana Peliciari. Escravos da Nação: o Público e o Privado na Escravidão brasileira, 1760-1876. São Paulo: Ed. Usp, 2018.

SÁ, Dominichi Miranda de. A ciência como profissão: médicos, bacharéis e cientistas no Brasil (1895-1935). Rio de Janeiro: Fiocruz, 2006.

SCHWARCZ, Lilia Moritz. O espetáculo das raças: cientistas, instituições e questão racial no Brasil 1870-1930. São Paulo: Companhia das Letras, 2014.

Letras, 2017.

Lima Barreto: triste visionário. São Paulo: Companhia das

Letras, 2019.

Sobre o autoritarismo brasileiro. São Paulo: Companhia das

\& STARLING, Heloisa Murgel. Brasil: uma biografia. São

Paulo: Companhia das Letras, 2015. 
O pós-abolição e o estigma do alienado no romance social O cemitério dos vivos, de Lima Barreto.

Revista Ensaios, vol. 14, jan-jun de 2019.

\& GOMES, Flávio (Orgs). Dicionário da Escravidão $e$ Liberdade. São Paulo: Companhia das Letras, 2018.

\& BOTELHO, André (Orgs). Cidadania, um projeto em construção: minorias, justiça e direitos. São Paulo: Claro enigma, 2012.

SEVCENKO, Nicolau. Literatura como missão: tensões sociais e criação cultural na Primeira República. 2. ed. São Paulo: Companhia das Letras, 2014.

SOUZA, Jassé. A elite do atraso: da escravidão à Lava Jato. Rio de Janeiro: Laya, 2017.

WACQUANT, Loïc. As duas faces do gueto. São Paulo: Boitempo, 2008.

WEBER, Max. Ensaios de sociologia. Rio de Janeiro: Zahar, 1979. 